\title{
In vitro Anti-Inflammatory Effects of Hyaluronic Acid in Ethanol-Induced Damage in Skin Cells
}

\author{
Manuela G. Neuman ${ }^{1,2}$, Radu M. Nanau ${ }^{1,2}$, Loida Oruña ${ }^{3}$, Gabriel Coto $^{4}$ \\ ${ }^{1}$ Departments of Clinical Pharmacology \& Toxicology, University of Toronto. \\ ${ }^{2}$ In Vitro Drug Safety \& Biotechnology, MaRS, Toronto, Canada. \\ ${ }^{3}$ State Center of Quality and Control of Drug Havana, Cuba. \\ ${ }^{4}$ Placentary Histotherapy Center - CHP, Havana Cuba; Research Biomedical Department, Havana, Cuba CIDEM, Center of \\ Pharmaceutical Chemistry, Latino-Americana Faculty of Medicine Havana, Cuba.
}

Received, June 5, 2011; Revised, October 20, 2011; Accepted, November 23, 2011; Published, November 26, 2011.

\begin{abstract}
Ethyl alcohol (ethanol) is commonly applied in cosmetic and pharmaceutical preparations, as well as disinfectant for chronic wounds. Objective: The present study aimed to appraise physiological levels of ethanol-induced damage in skin cells in vitro and the possible repair by hyaluronic acid (HA). In addition, we aimed to establish cytokine-chemokine networks in the cellular media and the modulation of cytokines such as tumor necrosis factor-alpha (TNF- $\alpha$ ), interferon-alpha (IFN- $\alpha$ ), transforming growth factor-beta (TGF- $\beta$ ), interleukins (IL) such as IL1- $\beta$ and IL-6, as well as matrix metalloproteinases (MMP) and tissue inhibitors of metalloproteinases (TIMP). Design and Methods: We treated human A431 epidermoid skin cells and mouse fibroblasts with ethanol at a concentration of $100 \mathrm{mM}$ over 24 hours (h). A separate experiment looked at the effects of 2 consecutive treatments with $100 \mathrm{mM}$ ethanol for $24 \mathrm{~h}$ each. HA obtained from umbilical cord excision was used at two concentration levels $(2 \%$ and $4 \%)$ to determine its efficacy in the treatment. We measured cytotoxicity and cytokine networks in the media. Results: Treatment of cells with $100 \mathrm{mM}$ ethanol increased cytotoxicity, as well as the release of pro-inflammatory cytokines into the culture medium. Conclusions: Ethanol may induce cytotoxicity in skin cells by enhancing the effects of pro-inflammatory cytokines. HA reduced the amount of pro-inflammatory cytokines released into the media both in human A431 epidermoid skin cells and in mouse fibroblasts.
\end{abstract}

This article is open to POST-PUBLICATION REVIEW. Registered readers (see "For Readers") may comment by clicking on ABSTRACT on the issue's contents page.

\section{INTRODUCTION}

Ethanol is a commonly used vehicle for both topical and parenteral drug preparations (1). A large variety of alcohols in different concentrations are used both in cosmetic products and as disinfectants (2-4).

Skin exposure to ethanol is a common occurrence in hospitals and health care facilities. In addition to its use in cosmetics, ethanol is used as a vehicle for contact allergy testing and to enhance skin permeability to drugs (5). Additionally, studies on the use of high concentrations of ethanol injections in allergic rhynitis have been described (6). Topical reactions include local cutaneous erythema, as observed macroscopically on patch testing (7).

Moreover, ethanol is used as a disinfectant of chronic wounds. Chronic non-healing wounds are a major health care problem; that may lead to disability and decrease quality of life (8). Among burn patients, skin replacement can save the life of an individual, and improve his/her quality of life (9).

In the United States, the therapeutic cost of chronic wound healing exceeds $\$ 10$ billion annually and constitutes over half of the total cost for all skin diseases $(10,11)$.

Corresponding Author: Manuela Neuman Ph.D., FACC Ass. Prof. of Pharmacology, Biophysics \& International Health; Department of Pharmacology \& Institute of Drug Research, Director In Vitro Drug Safety \& BioTechnology MaRS Discovery District, Toronto, Ontario, Canada Email:manuela.neuman@utoronto.ca 
Systemic conditions affecting wound healing include diabetes mellitus, trauma, inflammatory illnesses, metabolic abnormalities, coagulopathies, immunosuppression, smoking, malnutrition, and obesity (12). Many of these predisposing factors impair blood flow, resulting in local hypoxia that may decrease leukocyte bactericidal action by affecting oxidant-producing enzymes such as myeloperoxidase $(13,14)$.

There are also a variety of factors that promote inflammation within the chronic wound. High microbial burden leads to the presence of polymorphonuclear leukocytes within and around the wound. These cells promote inflammation. This inflammatory response encourages a sustained release of cytotoxic enzymes, cytokines and chemokines, matrix metalloproteinases, and free oxygen radicals $(15,16)$. These pro-inflammatory agents degrade the extracellular matrix, inhibit cell migration, and prevent wound closure (14). Therefore, promoting wound healing regardless of the nature of the agent that produced the inflammation is of pivotal importance.

Several groups including ours are searching for biomaterial that might be used in regenerative surgery employing HA (17-20). A cellular gel matrix-integrated implant system composed of a chitosan scaffold, gelatin and HA was used to treat full-thickness skin lesions in an experimental rabbit model (21). This formulation was well tolerated and led to a significantly higher survival rate, compared to animals allowed to heal in the absence of the integrated implant system (21).

The applications of an in vivo HA-based synthetic extracellular matrix system for the delivery of cells and molecules are varied, ranging from cancer biology to tumor imaging. Injectable and biocompatible vehicles for delivery, retention, growth and differentiation of stem cells are customized for use with progenitor and mature cell populations obtained from skin, fat, liver, heart, muscle, bone, cartilage, nerves and other tissues $(22,23)$. Namazi et al. described that healing during early gestation occurs quicker and is virtually scarfree (24). HA was used to enhance new skin formation for many years. Higher levels of HA have been observed during fetal wound healing compared to adult post-gestational wound healing. Also Namazi et al., observed less inflammation, as well as altered ratios of signaling molecules, such as higher ratios of TGF- $\beta 3$ to TGF- $\beta 1$ and TGF- $\beta 2$, and MMP to TIMP (24). Extracellular matrices containing hyaluronan have attracted attention because of their involvement in the proliferation, adhesion and migration of cells, and in infiltration by leukocytes, especially neutrophils $(19,25,26)$.

We have previously demonstrated that ethanol produced damage in epidermoidal cell lines and normal human keratinocytes in vitro (27-29). We have also described that $2 \%$ and $4 \%$ HA was able to repair lesions after ethanol-induced damage in human A431 line and in normal mouse fibroblast cells (29). In our previous work, we employed low physiological levels of ethanol, an inducer of cytochrome p450 2E1 (CYP2E1), to cause cell damage. The cytotoxic effect of ethanol included the release of pro-inflammatory cytokines and skin cell apoptosis (28-31). Since exposure to $100 \mathrm{mM}$ ethanol produced significant cytotoxicity in both human A431 cells and in mouse fibroblasts compared to cells that did not receive ethanol, we decided to employ this concentration in the present study. Moreover, we designed a chronic experiment by treating the cells with $100 \mathrm{mM}$ ethanol for two consecutive $24 \mathrm{~h}$ periods.

External and internal signals received by the skin can lead to cell death by necrosis or apoptosis (30). If the latter occurs, the cell's chromatin condenses and the DNA becomes fragmented, yet the integrity of the cell membrane is maintained. Cells are cleaved into apoptotic bodies and the apoptotic cells and apoptotic bodies are eliminated. As a result, potentially toxic metabolites that could harm healthy neighboring cells are not released $(28,31)$. Apoptosis, or programmed cell death, and the elimination of apoptotic cells are crucial factors in maintaining tissue health. Apoptosis allows cells to die without provoking a potentially harmful inflammatory response.

In contrast to necrosis, apoptosis is tightly controlled and regulated via several mechanisms, including the effects of cytokines such TNF- $\alpha$ and TGF- $\beta$. Efficient elimination of apoptotic cells is regulated by the expression of certain cell surface receptors. TNF- $\alpha$ is an inflammatory cytokine produced during acute inflammation and is responsible for a diverse range of signaling events within cells, leading to either necrosis or apoptosis. Furthermore, TNF- $\alpha$ is associated with fibroblast inflammation in rodents. There is an apparent and critical dichotomy. Tumor necrosis factor receptor1 assembles a signaling complex that can promote 
both cell death and survival. Alteration of virtually any intracellular apoptosis-related factor can change the balance towards cell survival. The dependence on chemokine/cytokine milieu may be central to understanding the paradox of the opposing functional capacities of TNF- $\alpha$. However, cells can be refractory to TNF- $\alpha$, owing to the overexpression of anti-apoptotic proteins, such as nuclear factor-kappa B (NF- $\kappa \mathrm{B})$ and mitochondrial apoptotic pathway-related factors (32).

IL-6 is a multifunctional cytokine that regulates the immune response, the acute phase response, and inflammation. Deregulation of IL-6 production is implicated in the pathology of several disease processes. Importantly, IL-6 is involved in both a pro-inflammatory and anti-inflammatory cytokine release (32).

We demonstrated that apoptosis in A431 epidermoid skin cells was triggered in a variety of ways, one of which is a cytokine-mediated process. Cytokines interacted with their receptors located on the surface of A431 epidermoid skin cells and initiated a cascade of events, including caspase enzyme activation and disruption of mitochondrial membrane potential, both of which led to cell death (27).

The current work attempts to elucidate the mechanism of chronic ethanol-induced skin-damage and the role played by HA in cell repair.

\section{MATERIALS AND METHODS}

\section{Healing HA-jelly}

Healing HA jellies at concentrations of $2 \%$ and $4 \%$ were formulated at the Placentary Histotherapy Center in Cuba. The manufacturing process consisted of separating residual umbilical cords from human placentas obtained according to the National Recollection Program in Cuba. HA is a viscous polysaccharide that belongs to the glycosaminoglycan group. HA is synthesized by fibroblasts, as well as smooth muscle, vascular epithelium and endothelial cells (18).

\section{Experiments with cultured cells}

Human A431 epidermoid skin cells were used in all experiments. This cell line has previously been shown to metabolize ethanol (27). A431 cells were obtained from the Wistar Institute (Philadelphia, PA, USA). Mouse skin fibroblasts in primary culture were cultured in the same conditions. The cells were centrifuged at 1,200 rpm for $10 \mathrm{~min}$, and the keratinocytes pellet was resuspended in medium for human keratinocytes containing $1 \mathrm{ml}$ of N-2hydroxyethylpiperazine-N-2-ethanesulfonic acid with growth factors (insulin $5 \mu \mathrm{g} / \mathrm{ml}$, hydrocortisone $0.5 \mu \mathrm{g} / \mathrm{ml}$, transferin $5 \mu \mathrm{g} / \mathrm{ml}$, triiodo thyronine sodium salt $2 \times 10^{-11} \mathrm{M}$ and sodium selenite $\left.10^{-8} \mathrm{M}\right), 100 \mu \mathrm{l}$ of epidermal cell growth factor, $2 \mu \mathrm{l}$ of cholera toxin, penicillin at $100 \mathrm{U} / \mathrm{ml}$, streptomycin at $10 \mu \mathrm{g} / \mathrm{ml}$, and $0.16 \mathrm{mM}$ $\mathrm{Ca}^{2+}$.

\section{Experimental design}

For each experiment, cells were seeded in microplates $\left(1 \times 10^{6}\right.$ cells $\left./ \mathrm{mL}\right)$. At the end of the incubation period, the medium was transferred onto 96-well trays (100 $\mu 1$ per sample) for cytokine determination. The A431 epidermoid skin cells were grown in $\alpha$-MEM supplemented with $10 \%$ (vol./vol.) heat-inactivated fetal bovine serum, 1\% nonessential amino acids, $1 \%$ glutamine, penicillin at $100 \mathrm{U} / \mathrm{ml}$ and streptomycin at $10 \mu \mathrm{g} / \mathrm{ml}$. Cells were maintained in serial culture in a humidified atmosphere of $95 \%$ oxygen and $5 \%$ carbon dioxide at $37^{\circ} \mathrm{C}$. The $\mathrm{pH}$ of the medium was constantly monitored and maintained at 7.4.

Control cells were exposed only to plain medium for $24 \mathrm{~h}$. Other cells were treated with ethanol $(100 \mathrm{mM})$ for $24 \mathrm{~h}$, or, for chronic experiments, with two consecutive doses of ethanol $(100 \mathrm{mM})$ for two consecutive periods of $24 \mathrm{~h}$, in the presence or in the absence of HA. All components were filter sterilized, and the entire procedure was conducted under aseptic conditions.

The viability of cells was measured using the 3(4,5-dimethylthiazol-2-yl) 2,5 diophenyltetrazolium bromide (MTT) assay as previously described (27). Also, we measured apoptosis in a parallel set of cells.

\section{Drugs and chemicals}

Ethanol was purchased from Alcohol Ltd. (Toronto, Ontario, Canada). $\alpha$-MEM and calcium chloride were purchased from Gibco (Burlington, Ontario, Canada). Bovine standard albumin, MTT, and all other chemicals were obtained from Sigma Co. (St. Louis, MO, USA). 


\section{TGF- $\beta$, TNF- $\alpha$, IFN- $\alpha$, ILs, metalloproteinases measurements}

We used Cytoscreen Immunoassay kits to measure mouse ILs, MMPs, IFN- $\alpha$, TGF- $\beta$ and TNF- $\alpha$ (In Vitrogen-Biosource International Camarillo, CA, USA). The cytokine mouse kit is based on a solid phase sandwich Enzyme-Linked-Immuno-Sorbent Assay (ELISA). A monoclonal antibody specific for each mouse cytokine has been coated onto the wells of the microtiter plate. For samples, including standards of known cytokine content, control and specimens undergoing the first incubation, the mouse antigen binds to the immobilized antibody on one site. After washing, a biotinylated monoclonal antibody specific for the mouse cytokine is added. During the second incubation, this antibody binds to the immobilized antibody that was captured during the first incubation.

For human measurements of IFN- $\alpha$, TGF- $\beta$ and TNF- $\alpha$, we used Cytoscreen Immunoassay kits, (In Vitrogen-Biosource International, Camarillo, CA, USA). To assay human MMPs and ILs, we used the following kits: IL-1 $\beta$, IL-6, (eBioscience, San Diego, CA), MMP-3, TIMP-1 and TIMP-2 (R\&D System, Minneapolis, USA) and the apoptosis kit (Bender, MedSystem, Austria). Procedures for quantification of these factors were performed according to the manufacturers' protocols using standard curves obtained from purified recombinant standards. Each sample was analyzed in duplicates and monitored. We used ELISA for the quantitative determination of cytokines in cell culture medium as previously described (27). The correlation coefficients were linear $(\mathrm{r}=0.989$ for human and $\mathrm{r}$ $=0.975$ for mouse) in a concentration range between $2 \mathrm{pg} / \mathrm{ml}$ and $500 \mathrm{pg} / \mathrm{ml}$ for TNF- $\alpha$ and $(\mathrm{r}=$ 0.980 for human and $r=0.960$ for mouse) for IFN$\alpha$. All other cytokines have been in a concentration range between $10 \mathrm{pg} / \mathrm{ml}$ and $300 \mathrm{pg} / \mathrm{ml}$.

\section{Cytotoxicity assay}

Cytotoxicity was assayed using the MTT assay, which is based on the conversion of the yellow tetrazolium bromide MTT to the purple formazan derivative, by the mitochondrial enzyme succinate dehydrogenase in viable cells $(27,28,30)$. The cells were washed with $0.2 \mathrm{~mL}$ PBS and assayed for cytotoxicity in the same tray. For the treated cells, toxicity was expressed as a percentage (where toxicity in control cells was considered to be $0 \%$ ). All determinations were carried out in each plate in sextuplicates, and five plates were used in each experiment.

\section{Measurement of apoptosis}

The A431 cells underwent lysis and were exposed to the detector antibody for cell lysate. After $1 \mathrm{~h}$ at room temperature, the cells were washed and incubated for another $30 \mathrm{~min}$ with SA-HRP (horseradish peroxidase) conjugate. The chromogene reaction was stopped, and the absorbance was read using a spectrophotometer plate reader with dual wavelengths of $450 \mathrm{~nm}$ and $595 \mathrm{~nm}$. The intensity of the yellow color was proportional to the number of nucleosomes in the sample. For each treatment, six wells per plate in five different plates were quantitated. The results were reported as percent apoptosis versus control, with non-treated cells taken as $0 \%$ apoptosis. The standard curve was composed of six replicates from each plate. The sensitivity of the assay was determined by assaying non-treated cells at time zero. The results are given by calculating the mean signal and standard deviation (SD). The assay was able to distinguish $0.3 \%$ from zero.

\section{Data collection and statistical analysis}

The Maxline Microplate Reader (Molecular Device Corporation, Menlo Park, CA, USA) was used to perform the MTT assay and to determine the release of cytokines into medium. It was connected to a computer using SOFT MAX software 2.3 for Windows (Molecular Device Corporation, Menlo Park, CA, USA), enabling the programming of the template, according to specific experimental needs for each of the end points.

Results are expressed as mean $\pm \mathrm{SD}$. A $P$ value of less than 0.05 was considered significant. A paired Student $t$-test was used to compare means between groups. Differences between groups were analyzed using an unpaired $t$-test assuming unequal variance. One-way ANOVA was used to calculate differences between two consecutive similar treatments within the group. All statistical analyses were performed with the software package SPSS 12.0.

\section{RESULTS}

\section{Cytotoxicity}

Exposure to $100 \mathrm{mM}$ ethanol for $24 \mathrm{~h}$ resulted in higher cytotoxicity $(p<0.001)$ than the to control 
treatment, with $24 \% \pm 7.2 \%$ cytotoxicity for mouse fibroblasts and $18 \% \pm 2.5 \%$ cytotoxicity for human A431 cells. The cytotoxicity of two consecutive 24 $\mathrm{h}$ each treatments with $100 \mathrm{mM}$ ethanol for was also significantly higher $(p<0.05)$ than the cytotoxicity produced by one exposure to $100 \mathrm{mM}$ ethanol for $24 \mathrm{~h}$, with $30 \% \pm 2 \%$ cytotoxicity for mouse fibroblast and $26 \% \pm 1.2 \%$ cytotoxicity for human A431 cells. In mouse fibroblasts, the presence of HA $4 \%$ resulted in a reduced toxicity when compared with the treatment of cells with ethanol alone $(\mathrm{p}<0.001)$ in both acute $14 \% \pm 4 \%$ and chronic exposure $20 \% \pm 2 \%$. In A431 cells, the presence of HA $4 \%$ resulted in a reduced toxicity when compared with the treatment of cells with ethanol alone $(\mathrm{p}<0.001)$ in both acute $8 \% \pm 2 \%$ and chronic exposure $18 \% \pm 2 \%$.

In Figure 1 we present graphically cytotoxicity to ethanol (Et-OH) in A431 epidermoid skin cells (white with a dash pattern) and mouse fibroblasts (solid black), as well as, the efficacy of HA preparation in reducing the cell toxicity. Cells were plated in 96-well microplates and grown until a cell density of $1 \times 10^{6}$ cells per milliliter was reached. A first set of cells was treated for a 24 hour period with either plain media (control cells), or ethanol $(100 \mathrm{mM})$, or ethanol $(100 \mathrm{mM})+2 \% \mathrm{HA}$, or ethanol $(100 \mathrm{mM})+4 \%$ HA. A second set of cells was exposed for 2 consecutive periods of 24 hours to the same treatment. After the first 24 hours the media was removed from the wells and new media was added as follows: plain media (control cells), or ethanol $(100 \mathrm{mM})$, or ethanol $(100 \mathrm{mM})+2 \% \mathrm{HA}$, or ethanol $(100 \mathrm{mM})+4 \%$ HA. Cytotoxicity was measured using the MTT assay. Cytotoxicity is expressed as a percentage mean $\pm \mathrm{SD}$, with control toxicity considered $0 \% . \quad * P<0.05$ increase in toxicity vs. $24 \mathrm{~h}$ treatment with $100 \mathrm{mM}$ ethanol; ** $P<0.05$ increase in toxicity vs. $24 \mathrm{~h}$ treatment with $100 \mathrm{mM}$ ethanol.

\section{Cytokine release}

The concentrations of cytokines released from mouse fibroblasts and A431 cells into the culture medium after $24 \mathrm{~h}$ or after two consecutive exposures to ethanol in the presence or absence of HA are presented in Table 1 for TNF- $\alpha$ and in Table 2 for IFN- $\alpha$. The concentrations of TNF- $\alpha$ and IFN- $\alpha$ in the medium of cells treated with 100 $\mathrm{mM}$ ethanol for $24 \mathrm{~h}$ were significantly different from those of control cells. HA at $4 \%$ was able to significantly lower the production of TNF- $\alpha$ in the $100 \mathrm{mM}$ ethanol treatment for both cell lines. Low doses of HA cause significant elevations in IFN- $\alpha$ levels in A431 cells treated with $100 \mathrm{mM}$ and significant decreases in IFN- $\alpha$ levels in mouse fibroblasts treated with $100 \mathrm{mM}$ ethanol.

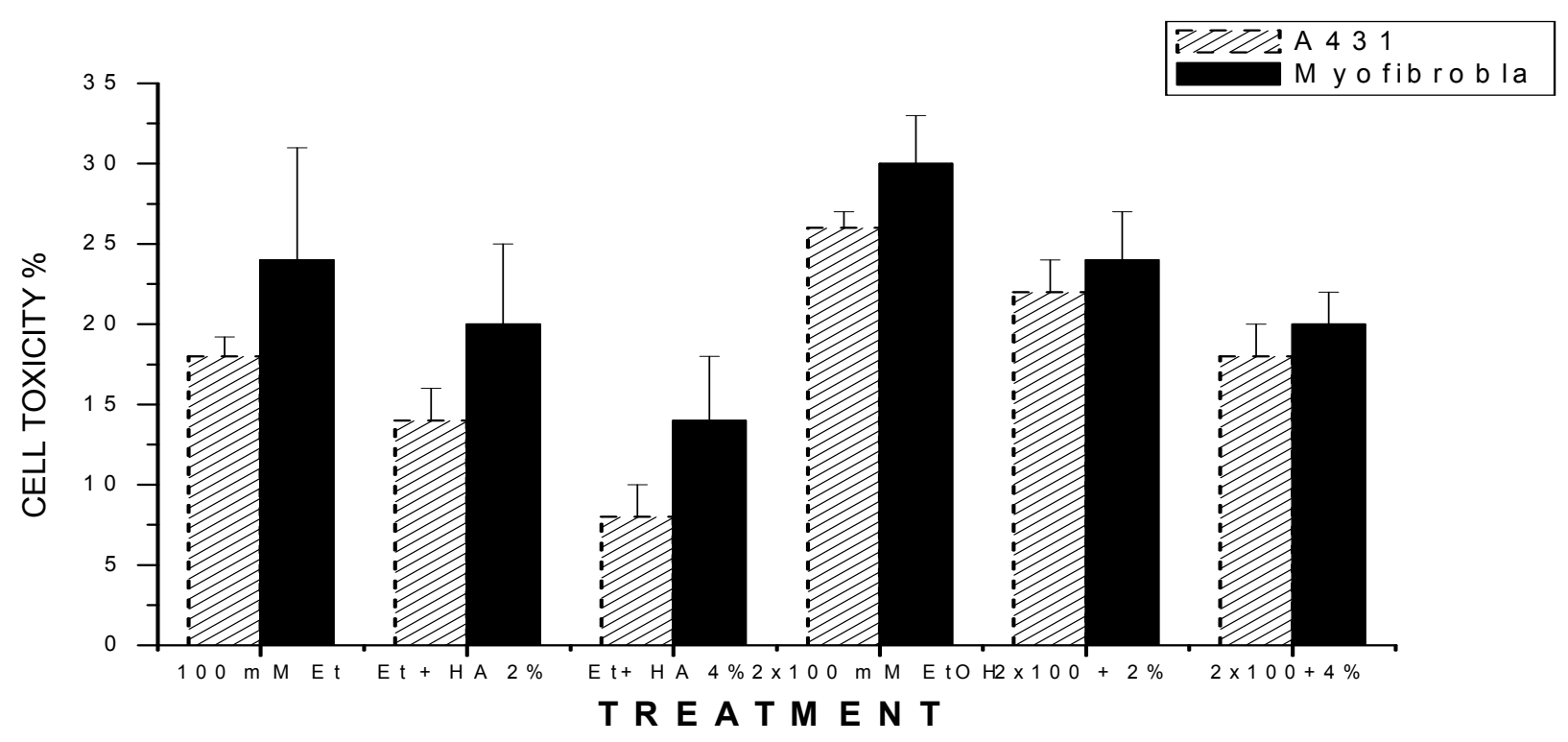

Figure 1 Hyaluronic acid reduces ethanol (Et-OH)-induced cytotoxicity in A431 epidermoid skin cells (white with a dash pattern) and mouse fibroblasts (solid black) 
At $70 \%-80 \%$ confluence, cells were incubated for 24 hours with ethanol $(100 \mathrm{mM})$ in the presence or absence of HA $(2 \%$ or $4 \%)$. After 24 hours of exposure, the experiment was stopped for one set of cells (control 24 hours; treated with $100 \mathrm{mM}$ ethanol for 24 hours in the presence or absence of HA).

The supernatant containing the products released during the 24 hours period was collected and stored at $-80^{\circ} \mathrm{C}$. The aliquots of the supernatant were checked for TNF- $\alpha$ released by cells into media. A second set of cells has been exposed for an extra 24 hours to an additional dose of ethanol $(100 \mathrm{mM})$ in the presence or absence of an additional HA $(2 \%$ or $4 \%)$. Control cells were exposed to plain media only. The media was changed with new, fresh plain media after the first 24 hours TNF- $\alpha$ release into media was measured in five different trays in triplicate and is reported as picograms per milliliter $(\mathrm{pg} / \mathrm{mL})$. Cytoscreen Immunoassay Kits for mouse and human TNF- $\alpha$ were used for the quantitative determination in cell culture medium. The results are shown as mean \pm
SD $\quad * P<0.05$ increased vs. control; ${ }^{* *} P<0.05$ decreased vs. ethanol treatment for $24 \mathrm{~h}$ at the corresponding dose.

At $70 \%-80 \%$ confluence, cells were incubated for 24 hours with ethanol $(100 \mathrm{mM})$ in the presence or absence of HA ( $2 \%$ or $4 \%)$. Control cells were exposed to plain media only. After 24 hours of exposure, the experiment was stopped for one set of cells and the supernatant was checked for cytokine release. A second set of cells has been exposed for an additional day to fresh plain media (control), or ethanol $(100 \mathrm{mM})$ in the presence or absence of HA $(2 \%$ or $4 \%)$. IFN- $\alpha(\mathrm{pg} / \mathrm{mL})$ release into medium was measured in five different trays in triplicate. Cytoscreen Immunoassay Kits for mouse and human IFN- $\alpha$ were used for the quantitative determination. The results are shown as mean $\pm \mathrm{SD}$ $* P<0.05$ increased vs. control; ${ }^{* *} P<0.05$ decreased vs. ethanol treatment for $24 \mathrm{~h} ; * * * P<0.05$ increased vs. ethanol treatment for $24 \mathrm{~h}$.

\begin{tabular}{|c|c|c|}
\hline Treatment & Mouse Fibroblasts & A431 Cells \\
\hline Control (24 hours) & $12.8 \pm 0.8$ & $15.8 \pm 0.8$ \\
\hline Control ( $2 \times 24$ hours $)$ & $12.0 \pm 1.5$ & $14.0 \pm 1.5$ \\
\hline $100 \mathrm{mM}$ ethanol (24 hours) & $26.6 \pm 2.0^{*}$ & $38.6 \pm 1.2^{*}$ \\
\hline $100 \mathrm{mM}$ ethanol ( $2 \times 24$ hours $)$ & $30.0 \pm 0.4^{*}$ & $40.2 \pm 0.2 *$ \\
\hline $2 \% \mathrm{HA}+100 \mathrm{mM}$ ethanol (24 hours) & $24.0 \pm 1.0$ & $20.6 \pm 1.0^{* *}$ \\
\hline $4 \% \mathrm{HA}+100 \mathrm{mM}$ ethanol (24 hours) & $18.0 \pm 2.0^{* *}$ & $16.0 \pm 1.2^{* *}$ \\
\hline $2 \% \mathrm{HA}+100 \mathrm{mM}$ ethanol ( $2 \times 24$ hours $)$ & $22.6 \pm 2.0^{*}$ & $24.5 \pm 1.2^{*}$ \\
\hline $4 \% \mathrm{HA}+100 \mathrm{mM}$ ethanol ( 2 × 24 hours $)$ & $16.0 \pm 2.0^{* *}$ & $18.6 \pm 1.2^{* *}$ \\
\hline
\end{tabular}

Table 2. IFN- $\alpha$ release into culture media by mouse fibroblasts and human A431 epidermoid skin cells exposed to $100 \mathrm{mM}$ ethanol for either 24 hours or 2 consecutive courses of 24 hours in the presence or in the absence of HA

\begin{tabular}{|c|c|c|}
\hline Treatment & Mouse Fibroblasts & A431 Cells \\
\hline Control (24 hours) & $22.5 \pm 0.5$ & $25.0 \pm 0.5$ \\
\hline Control ( 2 x 24 hours $)$ & $22.0 \pm 1.5$ & $24.0 \pm 1.5$ \\
\hline $100 \mathrm{mM}$ ethanol (24 hours) & $30.0 \pm 2.0 *$ & $32.0 \pm 4.0 *$ \\
\hline $100 \mathrm{mM}$ ethanol ( 2 × 24 hours $)$ & $34.0 \pm 0.4^{*}$ & $36.2 \pm 0.2 *$ \\
\hline $2 \% \mathrm{HA}+100 \mathrm{mM}$ ethanol (24 hours) & $22.0 \pm 2.0^{* *}$ & $40.0 \pm 1.0^{* * *}$ \\
\hline $4 \%$ HA $+100 \mathrm{mM}$ ethanol (24 hours) & $18.0 \pm 2.0^{* *}$ & $42.0 \pm 1.2 * * *$ \\
\hline $2 \% \mathrm{HA}+100 \mathrm{mM}$ ethanol $(2 \times 24$ hours $)$ & $22.6 \pm 2.0^{*}$ & $24.5 \pm 1.2 *$ \\
\hline $4 \% \mathrm{HA}+100 \mathrm{mM}$ ethanol $(2 \times 24$ hours $)$ & $16.0 \pm 2.0^{* *}$ & $18.6 \pm 1.2 * *$ \\
\hline
\end{tabular}


The release of IL- $1 \beta$ and IL- 6 after a one dose exposure to $100 \mathrm{mM}$ ethanol (A431: IL-1 $\beta 21.2 \pm$ $2.5 \mathrm{pg} / \mathrm{mL}$; IL-6: $21.6 \pm 1.5 \mathrm{pg} / \mathrm{mL}$; mouse: IL- $1 \beta$ $16.2 \pm 2.0 \mathrm{pg} / \mathrm{mL}$; IL-6: $18.5 \pm 1.5 \mathrm{pg} / \mathrm{mL}$ ) was significantly different $(\mathrm{p}<0.05)$ from the control or from two consecutive $24 \mathrm{~h}$ exposures to $100 \mathrm{mM}$ ethanol (A 431: IL-1 $\beta 28.5 \pm 2.5 \mathrm{pg} / \mathrm{mL}$ and IL-6 $24.8 \pm 0.5 \mathrm{pg} / \mathrm{mL} ; \mathrm{IL}-1 \beta 26.5 \pm 1.5 \mathrm{pg} / \mathrm{mL}$ and IL-6 $20.0 \pm 0.5 \mathrm{pg} / \mathrm{mL}$ ). HA addition did not change significantly the release of the tested ILs in media. Also, there were no significant differences between the types of cells.

TGF- $\beta$ values increase significantly after exposure to ethanol in both mouse fibroblasts and A431 cells, compare to control. However, these levels were not changed significantly after HA exposure (Table 3). The levels of MMP-1 and TIMP-1 in media did not show significant changes during the treatment with ethanol or with HA.

At $70 \%-80 \%$ confluence, cells were incubated for 24 hours with ethanol $(100 \mathrm{mM})$ in the presence or absence of HA $(2 \%$ or $4 \%)$. Control cells were exposed to plain media only. After 24 hours of exposure, the experiment was stopped for one set of cells and the supernatant was checked for TGF- $\beta$ release into culture media. A second set of cells has been exposed for an additional day to fresh plain media (control), ethanol $(100 \mathrm{mM})$ in the presence or absence of HA $(2 \%$ or $4 \%)$. TGF- $\beta(\mathrm{ng} / \mathrm{mL})$ release into medium was measured in five different trays in triplicate. Cytoscreen Immunoassay Kits for mouse and human TGF- $\beta$ were used for the quantitative determination of TGF- $\beta$ in cell culture medium. The results are shown as mean \pm SD ${ }^{*} P<0.05$ increased vs. control; ${ }^{* *} P<0.05$ decreased vs. ethanol treatment for $24 \mathrm{~h}$; $\# P<0.05$ increased vs. ethanol treatment for $24 \mathrm{~h}$.

\section{Apoptosis}

We measured the ethanol-induced increase in the percentage of apoptotic A431 cells (Figure 2). Treatment with $100 \mathrm{mM}$ ethanol resulted in a $16 \%$ increase in apoptosis over control $(p<0.001)$. After two consecutive $24 \mathrm{~h}$ treatments with $100 \mathrm{mM}$ ethanol, there was a $24 \%$ apoptosis. The level of apoptosis was significantly increased compared to control $(p<0.001)$ and compared to cells that had received only one $24 \mathrm{~h}$ treatment with $100 \mathrm{mM}$ ethanol $(p<0.05)$. Exposure to $2 \% \mathrm{HA}$ did not change significantly the percentage of apoptotic cells in $24 \mathrm{~h}$ treated cells or in two consecutive $24 \mathrm{~h}$ treatments. However the percentage of apoptotic cells was significantly reduced in cells treated concomitantly with ethanol and HA 4\% treated $(\mathrm{p}<0.05)$ compared to cells not exposed to HA (Figure 2). Figure 2 and Figure 3 - Cells were plated in 96-well microplates and grown until a cell density of $1 \times 10^{6}$ cells $/ \mathrm{mL}$ was reached. Cells were treated for a 24 hour period with either ethanol (100 $\mathrm{mM})$, or with ethanol $(100 \mathrm{mM})+2 \% \mathrm{HA}$, or with ethanol $(100 \mathrm{mM})+4 \%$ HA. A second set of cells was exposed for 2 consecutive 24 hours to the same treatment. Apoptosis was measured using the M30 assay. Apoptosis is expressed as a percentage mean $\pm \mathrm{SD}$, with control toxicity considered $0 \%$. ${ }^{*} P<0.05$ increase in toxicity vs. $24 \mathrm{~h}$ treatment with $100 \mathrm{mM}$ ethanol; ** $P<0.05$ increase in toxicity vs. $24 \mathrm{~h}$ treatment with $100 \mathrm{mM}$ ethanol.

\begin{tabular}{|c|c|c|}
\hline Treatment & Mouse Fibroblasts & A431 Cells \\
\hline Control (24 hours) & $5.8 \pm 0.8$ & $6.8 \pm 1.8$ \\
\hline Control ( 2 x 24 hours $)$ & $5.0 \pm 1.5$ & $6.0 \pm 1.5$ \\
\hline $100 \mathrm{mM}$ ethanol (24 hours) & $6.6 \pm 2.0$ & $8.6 \pm 1.2$ \\
\hline $100 \mathrm{mM}$ ethanol ( 2 × 24 hours $)$ & $16.0 \pm 0.4 * \#$ & $20.2 \pm 1.2 * \#$ \\
\hline $2 \% \mathrm{HA}+100 \mathrm{mM}$ ethanol (24 hours) & $7.0 \pm 1.0$ & $10.6 \pm 1.0$ \\
\hline 4\% HA +100 mM ethanol (24 hours) & $7.5 \pm 1.0$ & $12.6 \pm 1.0 *$ \\
\hline $2 \% \mathrm{HA}+100 \mathrm{mM}$ ethanol ( $2 \times 24$ hours $)$ & $6.6 \pm 2.0 * *$ & $12.5 \pm 1.2 * *$ \\
\hline $4 \% \mathrm{HA}+100 \mathrm{mM}$ ethanol ( $2 \times 24$ hours $)$ & $12.0 \pm 2.0^{* *}$ & $18.6 \pm 0.2 * *$ \\
\hline
\end{tabular}




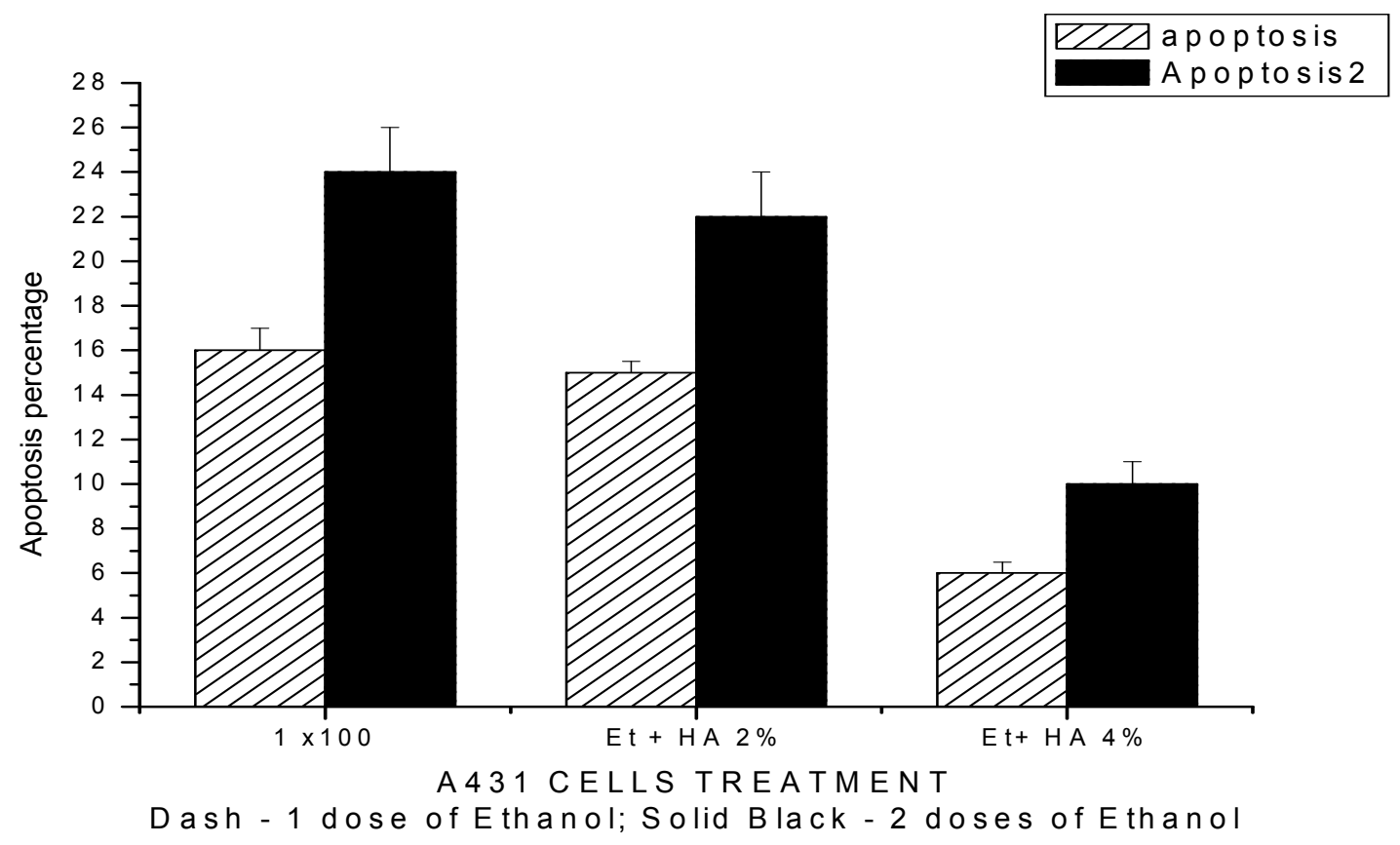

Figure 2. Ethanol (Et) induced apoptosis in A431 - One-dose/24 hours is represented in the dashed-columns. Two treatments for 2 consecutive 24 hours period are shown in solid-black columns.

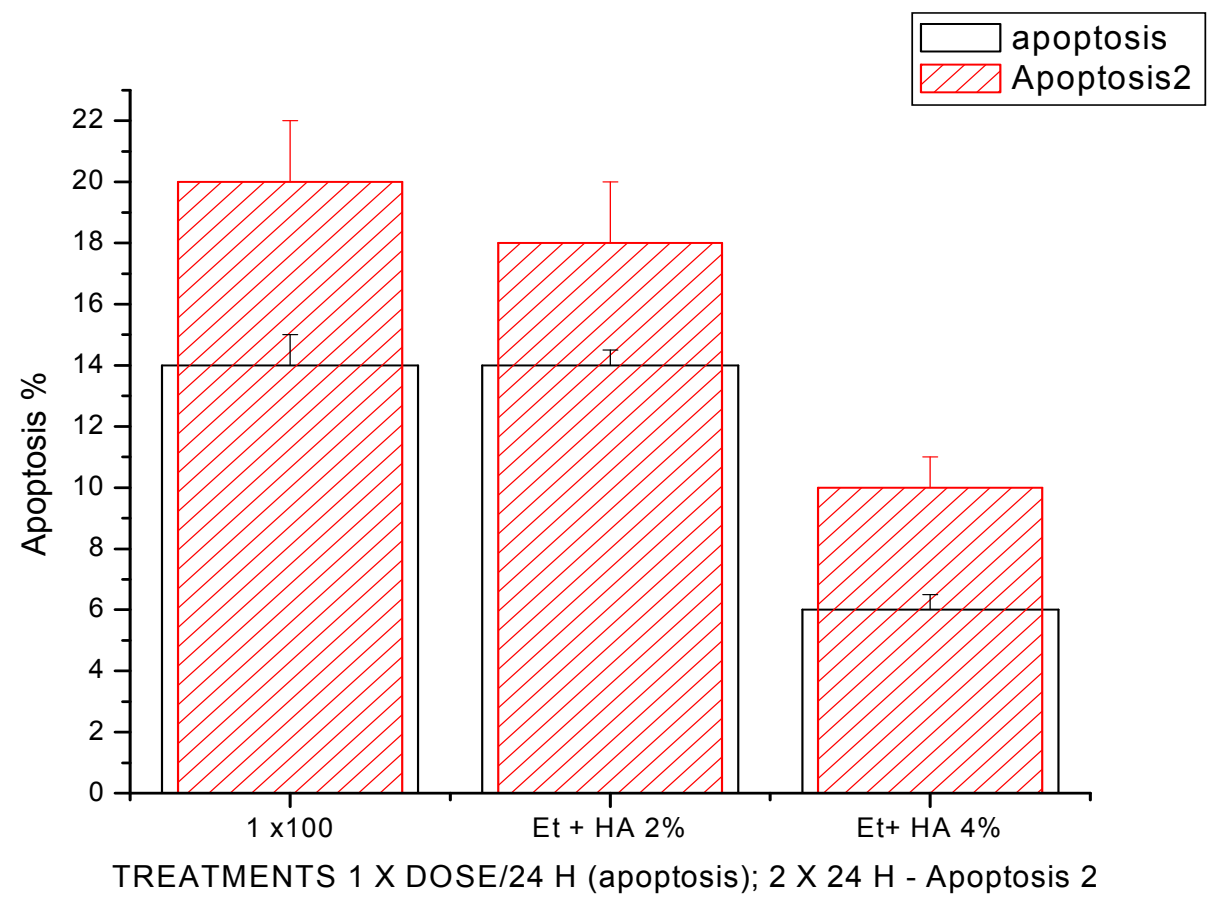

Figure 3. Ethanol-induced apoptosis in myofibroblasts - Apoptosis in myofibroblast treated 1-dose/24 hours is shown in the black box. The red dashed box represent the apoptosis in the culture treated 2 doses during two periods of 24 hours. 


\section{DISCUSSION}

We hypothesized that exposure to even low, physiological doses of ethanol, would cause damage in A431 epidermoid skin cells and mouse fibroblasts in vitro. We found that over a $24 \mathrm{~h}$ period, a $100 \mathrm{mM}$ concentration of ethanol caused higher cytotoxicity, compared to the control cells. This was also shown in a previous work, which describes dose-response toxicity associated with 50 $\mathrm{mM}$ and $100 \mathrm{mM}$ ethanol over $24 \mathrm{~h}$ exposure (29). Also, it is important to notice the difference in the percentages of apoptosis and cytotoxicity, which represents the percentage of cells that died by necrosis.

In the current study, we focused on the role of the pro-inflammatory cytokines TNF- $\alpha$ and IFN- $\alpha$ in ethanol-induced chronic skin cell toxicity. In addition, we studied changes in MMPs and TGF- $\beta$ in these models. Two cytokines, TNF- $\alpha$ and IFN- $\alpha$, strongly influence inflammation and apoptotic processes (30). TNF- $\alpha$ is an inflammatory cytokines; among other functions, it triggers the production of additional cytokines. Together, these cytokines attract inflammatory cells to the organ, destroy cells, and/or initiate a healing response that includes the formation of scar tissue. Thus, a vicious cycle would be established in the cells: TNF- $\alpha$ promotes reactive oxygen species production, reactive oxygen species production activates $\mathrm{NF}-\kappa \mathrm{B}$, and NF- $\mathrm{KB}$ leads to enhanced production of additional TNF- $\alpha$ and its receptor, as well as to the production of apoptosis-promoting factors (31). IFN- $\alpha$ may reduce scar formation. This cytokine decreases the proliferation rate of fibroblasts and reduces the rate of collagen synthesis (33). On the basis of results presented in this study, the main cytokine implicated in skin cell damage by ethanol seems to be TNF- $\alpha$. Both mouse fibroblasts and human A431 epidermoid skin cells released greater amounts of TNF- $\alpha$ upon exposure to ethanol, even at the lower concentration of 50 $\mathrm{mM}$ ethanol. The presence of this cytokine in the media was previously shown to produce by itself both apoptosis and necrosis in skin cells $(27,32)$.

TNF- $\alpha$ has many immunomodulatory effects, and it can trigger apoptosis by binding to the TNF$\alpha$ receptor on cell surface (31). We observed that treatment with ethanol was associated with an increase in apoptosis, compared to findings for control. In A431 cells exposed to low doses of HA, the levels of IFN- $\alpha$ increased significantly. This may be one of the explanations for better survival of these cells versus the cells treated with ethanol only.

Differences between cell lines were not only observed in their response to ethanol, but also in the amount of cytokines produced upon exposure to ethanol. Both human A431 cells and mouse fibroblasts were able to metabolize ethanol and were useful in modeling the skin's response to ethanol exposure. Low concentration of HA (2\% and 4\%) signal for repair in skin cells.

Ethanol-induced skin toxicity is a complex process that probably involves alterations in cytokine production, enhancement of the cytotoxic actions of certain cytokines, and changes in the apoptotic activity, leading to ultrastructural changes of skin cells. The present work demonstrates that TNF- $\alpha$ plays an important role in ethanol-induced toxicity in our models. HA in lower concentrations may signal for anti-apoptotic events in skin cells. Also, IFN- $\alpha$ levels are modulated by $\mathrm{HA}$ at low concentrations. HA's wound healing and antiinflammatory benefits are supported by in vivo and in vitro studies throughout the literature. Matsumoto et al. (34) report that spongy sheets treated with HA and arginine appeared to cause a decrease in the size of wounds inflicted by either surgery or burning to the abdomen of male rats. Parker et al. (35) showed that HA and basic fibroblast growth factor-2 significantly reduces inflammation, preventing airway blockage in rabbits. Also, Iwata et al. (36) show that CD19, a response regulator of B-lymphocytes, regulates wound healing through HA-induced toll-like receptor (TLR)-4 signaling. Efforts are made to speed the repair of the injured tissue, a process that would naturally be slow (37). Injections with HA have been used to increases the viscosity of synovial fluid, thus absorbing shocks and limiting further damage to the cartilage (38). HA also stimulates proliferation of fibroblasts (39). Fibrins have excellent binding to HA, thus HA scaffolds can be used to bring these cells to the injury site, hold them in place, and enhance their growth and proliferation (40) without increasing the HA concentration (41). Furthermore, an HA hydrogel would allow for the insertion of molecules that would degrade it in time, when the cartilage would already have been built (42). HA is one of the main 
components used to create skin substitutes, and the HA-based scaffolds used to prepare these products are often preferred over artificial scaffolds. HA is used in wound healing, ophthalmology and joint surgery, and also as dermal filler (9). Wound healing is a complex process involving interactions among a variety of different cell types. The normal wound repair process consists of three phases (inflammation, proliferation and remodeling) that occur in a predictable series of cellular and biochemical events. Growth factors have the potential to heal wounds by stimulating angiogenesis and cellular proliferation, affecting the production and the degradation of the extracellular matrix (43). The involvement of alcohol in skin injury was shown to be a dynamic process (27). Glycosaminoglycans inhibit lysosomal cathepsin activities in a model of skin fibroblasts submitted to oxidative stress (44).

HA formulations can be used to improve the quality of life of burn victims, rather than just improve the survival rate of these patients (9). Several animal models mimic dermal neovascularization of skin cells. Oligosaccharides of HA are capable of stimulating neo-vascularization in vitro and promoting blood flow or angiogenesis in animal models (45). A complex made up of oligosaccharides of HA was used to promote the repair of tissue injury of a murine excision dermal wound (24). Following from these findings, Namazi et al. (24) describe a slow release formulation that allows a slow absorption of the material by the surrounding tissue. In fact, this slow-release lowmolecular weight HA formulation showed superior wound healing potential over control and highmolecular weight HA formulation by day 6 and day 8. Aside from the increased neo-blood and lymph vessels formed in wounded tissues treated by oligosaccharides of HA, treatments of wounds with this formulation resulted in more granulation, collagen deposition and fibroblast proliferation (24). Significant up-regulation of some cytokines (i.e. IL- $\beta 3$ ) or adhesion molecules in oligosaccharides of HA-treated wounds, corresponding with increased granulation tissue in these wounds, was observed. These findings suggested that therapy with oligosaccharides of HA might be useful in acute wound repair (45).

Aditional stimulation of epidermal calcium gradient loss was demonstrated to increase the expression of hyaluronan and its receptor CD44 in mouse skin (46). Ariel et al. (47) postulated that induction of interactions between CD44 and HA by a short exposure of human $\mathrm{T}$ cells to diverse proinflammatory mediators is part of wound healing. Other scientists argue that hyaluronan is an immune regulator in human diseases (48). Also, HA was found to down-regulate the expression of IL-1 $\beta$, TNF- $\alpha$ and MMP-3, and to up-regulate the expression of the anti-inflammatory cytokine IL-10 and that of TIMP-1 and MMP-2 in fibroblast-like synoviocytes collected from osteoarthritis patients with tibia plateau fracture (49). Overall, HA can promote the expression of both anti-inflammatory and structure-protective factors in fibroblast-like synoviocytes of patients with tibia plateau fracture (49).

We demonstrated in the present work that HA regulates cytokines and chemokines, which in turn influence inflammatory cell recruitment and chemotaxis. The actions of HA are dependent on its interacting with different types of cells. HA binds to an array of proteins to elicit its biological roles. The recent demonstration of HA-TLR interactions provides molecular insight into the mechanisms of HA signaling in inflammatory cells, as well as in epidermoid and fibroblast cells.

\section{CONCLUSION}

Hyaluronan regulates cytokines and other inflammatory substances and influences inflammatory cell recruitment and chemotaxis. In the present in vitro work in human A431 epidermoid skin cells and in mouse fibroblasts, we showed that ethanol-induced damage and HAinduced repair are both controlled by TNF- $\alpha$. Moreover, we presented the possibility of using HA as an immunomodulatory agent in in vitro models. Cytotoxicity due to ethanol exposure is frequencydependent. HA was shown to be protective. The cumulative interpretation of these data is that the pro-inflammatory and cytotoxic role of ethanol as well as the role of cytokines in regulating cell-HA interactions depends on the cell type.

Alcohol-induced damage to skin in vitro helps in the understanding of the role of TNF- $\alpha$ production in skin apoptosis. Our study includes cell surface receptor, extracellular matrix and cytoskeletal players mediating cell adhesion, migration, motility and morphogenesis, and cytokines controlling cell differentiation, 
development, growth and proliferation. In this model, HA protects the cells from membrane disruption, reduces levels of the pro-inflammatory cytokine TNF- $\alpha$, and inhibits apoptosis by enhancing membrane stability to promote cell survival. We suggest the existence of molecular links between HA and the regulation of apoptosis. From the present work, we conclude that possible repair of ethanol-induced skin damage by HA therapy may also have beneficial effects on acute wounds in a clinical setting.

\section{REFERENCES}

1. Cross SE, Roberts MS. The effect of occlusion on epidermal penetration of parabens from a commercial allergy test ointment, acetone and ethanol vehicles. J Invest Dermatol, 2000; 115:914918.

2. Rotter ML, Simpson RA, Koller W. Surgical hand disinfection with alcohols at various concentrations: parallel experiments using the new proposed European standards method. Infect Control Hosp Epidemiol, 1998; 19:778-781.

3. Kieć-Swierczyńska M, Krecisz B, SwierczyńskaMachura D. Contact allergy to fragrances. Med Pr, 2006; 57:431-437.

4. Cosmetic Ingredient Review Expert Panel. Final report of the safety assessment of Alcohol Denat., including SD Alcohol 3-A, SD Alcohol 30, SD Alcohol 39, SD Alcohol 39-B, SD Alcohol 39-C, SD Alcohol 40, SD Alcohol 40-B, and SD Alcohol 40-C, and the denaturants, Quassin, Brucine Sulfate/Brucine, and Denatonium Benzoate. Int J Toxicol, 2008; 27:S1-S43.

5. Pershing LK, Lambert LD, Knutson K. Mechanism of ethanol-enhanced estradiol permeation across human skin in vivo. Pharm Res, 1990; 7:170-175.

6. Wu MD, Kimura M, Nakayama M. Inafuku S. A New Treatment Method by Submucosal Ethanol/Steroid (E/S) Injection for Allergic Rhinitis: A Pilot Study. J Aichi Med Univ Assoc, 2007; 35:129-146.

7. Haddock NF, Wilkin JK. Cutaneous reactions to lower aliphatic alcohols before and during disulfiram therapy. Arch Dermatol, 1982; 118:157159.

8. Bergan JJ, Schmid-Schonbein GW, Coleridge PD, Nicolaides AN, Boisseau MR, Eklof B. Chronic venous disease. NEJM, 2006; 355:488-498.

9. Brusselaers N, Pirayesh A, Hoeksema H, Richters CD, Verbelen J, Beele H, Blot SI, Monstrey S. Skin replacement in burn wounds. J Trauma, 2010; 68:490-501.
10. Bickers DR, Lim HW, Margolis D, Weinstock MA, Goodman C, Faulkner E, Gould C, Gemmen E, Dall T. The burden of skin diseases: 2004 a joint project of the American Academy of Dermatology Association and the Society for Investigative Dermatology. J Am Acad Dermatol, 2006; 55:490500.

11. Kuehn BM. Chronic wound care guidelines issued. JAMA, 2007; 297:938-939.

12. Medina A, Scott PG, Ghahary A, Tredget EE Pathophysiology of chronic nonhealing wounds. J Burn Care Rehab, 2005; 26:306-319.

13. Bowler PG, Duerden BI, Armstrong DG Wound microbiology and associated approaches to wound management. Clin Microbiol Rev, 2001; 14:244269.

14. Mustoe T. Understanding chronic wounds: a unifying hypothesis on their pathogenesis and implications for therapy. Am J Surg, 2004; 187:65S-70S.

15. Sibbald RG, Contreras-Ruiz J, Coutts P, Fierheller M, Rothman A, Woo K Bacteriology, inflammation, and healing: a study of nanocrystalline silver dressings in chronic venous leg ulcers. Adv Skin Wound Care, 2007; 20:549-558.

16. Bjarnsholt $\mathrm{T}$, Kirketerp-Møller $\mathrm{K}$, Jensen $\mathrm{P} \varnothing$, Madsen KG, Phipps R, Krogfelt K, Høiby N, Givskov M. Why chronic wounds will not heal: a novel hypothesis. Wound Repair Regen, 2008; 16:210.

17. Reddi AH. Symbiosis of biotechnology and biomaterials: applications in tissue engineering of bone and cartilage. J Cell Biochem, 1994; 56:192195.

18. Papakonstantinou E, Karakiusalakis G, Karakiusalakis G, Roth M, Block L. Platelet-derive growth factor stimuilares the secretion of HA by proliferating human vascular smooth cells. Proc. Natl. Acad. Sci USA, 1995; 92:9881-9885.

19. Evanko SP, Angello JC, Wight TN. Formation of hyaluronan- and versican-rich pericellular matrix is required for proliferation and migration of vascular smooth muscle cells. Arterioscler Thromb Vasc Biol, 1999; 19:1004-1013

20. Itano N, Kimata K. Mammalian hyaluronan synthases. IUBMB Life, 2002; 54:195-199.

21. Weinstein-Oppenheimer CR, Aceituno AR, Brown DI, Acevedo C, Ceriani R, Fuentes MA, Albornoz F, Henriquez-Roldan CF, Morales P, Maclean C, Tapia SM, Young ME. The effect of an autologous cellular gel-matrix integrated implant system on wound healing. J Transl Med, 2010; 8:59.

22. Neuman MG, Katz G, Malkiewicz I, Mathurin P, Tsukamoto H, Adachi M, Ishii H, Colell A, GarcíaRuiz C, Fernández-Checa JC, Casey CA. Alcoholic 
liver injury and apoptosis. Alcohol, 2002a; 28:117128.

23. Prestwich G.D. Hyaluronic acid-based clinical biomaterials derived for cell and molecule delivery in regenerative medicine. J Control Release, 2011; doi:10.1016/j.jconrel.2011.04.007.

24. Namazi MR, Fallahzadeh MK, Schwartz RA. Strategies for prevention of scars: what can we learn from fetal skin? Int J Dermatol, 2011; 50:85-93.

25. Zimmermann DR, Dours-Zimmermann MT, Schubert M, Bruckner-Tuderman L. Versican is expressed in the proliferating zone in the epidermis and in association with the elastic network of the dermis. J Cell Biol, 1994; 124:817-825.

26. Taylor KR, Trowbridge JM, Rudisill JA, Termeer CC, Simon JC, Gallo RL. Hyaluronan fragments stimulate endothelial recognition of injury through TLR4. J Biol Chem, 2004; 279:17079-17084.

27. Shear NH, Malkiewicz IM, Klein D, Koren G, Randor S, Neuman MG. Acetaminophen-induced toxicity to human epidermoid cell line A431 and hepatoblastoma cell line HepG2, in vitro, is diminished by silymarin. Skin Pharmacol. 1995; 8:279-292.

28. Neuman MG, Haber JA, Malkiewicz IM, Cameron RG, Katz GG, Shear NH. Ethanol signals for apoptosis in cultured skin cells. Alcohol, 2002b; 26:179-190.

29. Neuman MG, Oruña L, Coto G, Lago G, Nanau RM, Vincent M. Hyaluronic acid signals for repair in ethanol-induced apoptosis in cultured skin cells. Clin Biochem, 2010; 43:822-826.

30. Neuman MG, Shear NH, Cameron RG, Katz GG, Tiribelli C. Ethanol-induced apoptosis in vitro. Clin Biochem, 1999; 32:547-555.

31. Neuman MG. Apoptosis in diseases of the liver. Crit Rev Clin Lab Sci, 2001; 38:109-166.

32. Katz GG, Shear NH, Malkiewicz IM, Valentino K, Neuman MG. Signaling for ethanol-induced apoptosis and repair in vitro. Clin Biochem, 2001; 34:219-227.

33. Wang J, Chen H, Shankowsky HA, Scott PG, Tredget EE. Improved scar in postburn patients following interferon-alpha $2 b$ treatment is associated with decreased angiogenesis mediated by vascular endothelial cell growth factor. J Interferon Cytokine Res, 2008; 28:423-434.

34. Matsumoto Y, Arai K, Momose H, Kuroyanagi Y. Development of a wound dressing composed of a hyaluronic acid sponge containing arginine. J Biomater Sci Polym Ed, 2009; 20:993-1004.

35. Parker NP, Bailey SS, Walner DL. Effects of basic fibroblast growth factor-2 and hyaluronic acid on tracheal wound healing. Laryngoscope, 2009; 119:734-739.
36. Iwata Y, Yoshizaki A, Komura K, Shimizu K, Ogawa F, Hara T, Muroi E, Bae S, Takenaka M, Yukami T, Hasegawa M, Fujimoto M, Tomita Y, Tedder TF, Sato S. CD19, a response regulator of B lymphocytes, regulates wound healing through hyaluronan-induced TLR4 signaling. Am J Pathol, 2009;175:649-660.

37. Kondo T, Shinozaki T, Oku H, Takigami S, Takagishi K. Konjac glucomannan-based hydrogel with hyaluronic acid as a candidate for a novel scaffold for chondrocyte culture. J Tissue Eng Regen Med, 2009; 3:361-367.

38. Sun SF, Chou YJ, Hsu CW, Chen WL. Hyaluronic acid as a treatment for ankle osteoarthritis. Curr Rev Musculoskelet Med, 2009; 2:78-82.

39. Solakoglu S, Tiryaki T, Ciloglu SE. The effect of cultured autologous fibroblasts on longevity of cross-linked hyaluronic acid used as a filler. Aesthet Surg J, 2009; 28:412-416.

40. Park SH, Cui JH, Park SR, Min BH. Potential of fortified fibrin/hyaluronic acid composite gel as a cell delivery vehicle for chondrocytes. Artif Organs, 2009; 33:439-447.

41. Kreger ST, Voytik-Harbin SL. Hyaluronan concentration within a 3D collagen matrix modulates matrix viscoelasticity, but not fibroblast response. Matrix Biol, 2009; 28:336-346.

42. Chung C, Beecham M, Mauck RL, Burdick JA. The influence of degradation characteristics of hyaluronic acid hydrogels on in vitro neocartilage formation by mesenchymal stem cells. Biomaterials, 2009; 30:4287-4296.

43. Molina P, McClain C, Valla D, Guidot D, Diehl AM, Lang C, Neuman M. Molecular pathology and clinical aspects of alcohol induced tissue injury. Alcoholism: Clin and Exper Research, 2002; 26:120-128.

44. Yue XL, Lehri S, Li P, Barbier-Chassefière V, Petit E, Huang QF, Albanese P, Barritault D, Caruelle JP, Papy-Garcia D, Morin C. Insights on a new path of pre-mitochondrial apoptosis regulation by a glycosaminoglycan mimetic. Cell Death Differ, 2009; 16:770-781.

45. Gao F, Liu Y, He Y, Yang C, Wang Y, Shi X, Wei G. Hyaluronan oligosaccharides promote excisional wound healing through enhanced angiogenesis. Matrix Biol, 2010; 29:107-116.

46. Lee SE, Jun JE, Choi EH, Ahn SK, Lee SH. Stimulation of epidermal calcium gradient loss increases the expression of hyaluronan and CD44 in mouse skin. Clin Exp Dermatol, 2010; 35:650-657.

47. Ariel A, Lider O, Brill A, Cahalon L, Savion N, Varon D, Hershkoviz R. Induction of interactions between CD44 and hyaluronic acid by a short exposure of human $\mathrm{T}$ cells to diverse pro- 
inflammatory mediators. Immunology, 2000; 100:345-351.

48. Jiang D, Liang J, Noble PW. Hyaluronan as an immune regulator in human diseases. Physiol Rev, 2011; 91:221-264.
49. Huang TL, Hsu HC, Yang KC, Lin FH. Hyaluronan up-regulates IL-10 expression in fibroblast-like synoviocytes from patients with tibia plateau fracture. J Orthop Res, 2011; 29:495-500. 